\title{
Contemporary Aesthetic Landscapes an Archaeological Look at Time Present
}

\author{
Óscar González Vergara* \\ Collaborator in Centro De Estudios De Arqueología Virtual-DIGITALMED, Spain
}

Submission: May 21,2019; Published: June 06, 2019

*Corresponding author: Óscar González Vergara, Collaborator in Centro De Estudios De Arqueología Virtual-DIGITALMED, Murcia, Spain

\begin{abstract}
In this work we synthesize our work by elaborating a methodological perspective for the study of contemporary society today. Especially the formation of a cultural and aesthetic landscape characteristic of the global world present.
\end{abstract}

Keywords: Time present; Landscape; Aesthetic; Contemporary archaeology

\section{Mini Review}

As a result of decades of consolidation of the theory and praxis of disciplines such as Archeology and Anthropology, together with discourses, methods and other research tools (such as Geography, History, Sociology and many more), now we have large amounts of information and alternative views that allow us to reinterpret the understanding of the past and the present. Archeology offers one of those new alternative views of the present times [1]. Whether as historical and chronological archeology (present time) or from a spatial and thematic perspective, today we have different perspectives that allow us to study the present with the characteristic rigor of the archaeological method, analyzing and interpreting the current tangible, intangible and spatial reality as if it were an archaeological site. The archaeologist's view of current society and landscape is fundamental. If Archeology as landscape, architecture or symbol opens the possibility of doing Archeology without having to carry out an excavation, centered on material and immaterial remains, geographical dispositions, and social relations, that would mean that current Archeology has different forms of studying contemporary subjects through cultural landscapes, memories, aesthetics, and relationships.

The excavation and prospection of the present imply incorporating the ethnographer, the geographer and the sociologist, not only to know what the social structure and present reality are but, above all, to explain and give meaning to the material and landscape reality of society. Archeology applied to contemporary contexts must not forget that its purpose is to explain the formation of cultural landscapes and the heritage remains that are generated, that have reached us and that we will bequeath to the future. Another issue is the use given to that material reality. Before an archaeological investigation of the historical past, where the land is excavated to find material rests and, from them, to extract socioeconomic, spatial, political, religious and artistic information, for present times these contemporary remains do not entail the same process of discovery and study. That material reality is still in use, it is alive. Prospecting is more useful than excavation, since, except in very specific cases, they are unburied material and spatial remains, at least in the physical sense. The work of excavation in most cases involves a work of analysis of strata, elements and intangible relationships, memories, identities and collective imaginaries that involve and give meaning to buildings, tools, spaces, etc., and human communities. The great difference is that we have to incorporate the subject who builds, lives, interprets and inherits that legacy; subject that becomes the object of archaeological analysis. The archaeologist is placed in the uncomfortable position of a researcher who makes archeology of the present, of their present, digging themselves as an integral part of society. In this sense, the emic-etic implications and professional ethics of how to excavate the present without assuming prejudices and subjectivities are very important.

On the other hand, that the archaeologist is part of the excavated 'site' allows to charge the results with meaning and to give information 'from within'. It is necessary to capture the forms in which contemporary reality is composed. Cities and rural areas, transport and communication systems, workspaces, housing and leisure, waste sites, etc.; all make up a landscape 
and an aesthetic properly contemporary. Although there are cultural, social and geographical differences, since the Industrial Revolution the process of globalization has drawn a cultural landscape that, in its most basic elements, is recognizable in practically all areas of the planet. The way of producing and consuming born in the factories has created an aesthetic that was linked to progress and has served as a basis for modeling productive environments and, outside them, for bringing industrial aesthetics to everyday contexts. It is as if the world had become a factory. Perhaps this explains that after postindustrialization processes in the West, together with processes of offshoring and industrialization of other parts of the planet, what we see is a constant industrial revolution in progress, transforming society, which spreads throughout the world. The techniques and science that have allowed the development of information and communication technologies have helped to expand and homogenize a contemporary aesthetic (of the factory and western capitalism), marked by the practical, the rational, the profitable, the chain of production, cost reduction, machining, and robotization... Its spaces and constructions, increasingly high, minimalist, light, intelligent, effective; in analogy to the evolution of industrial environments that were born of solid stone and brick constructions and that with the profuse use of metal, concrete and glass, became increasingly lighter, higher, diaphanous.

If constructions such as the Crystal Palace in London, the Eiffel Tower in Paris and the Statue of Liberty in New York helped to consolidate that industrial aesthetic as an aesthetic of the West, capitalism, and liberalism, in short, as an aesthetic of democracy, the new constructions of the present are making that factory aesthetic, which as before, is in constant transformation, a whole planetary, global aesthetic. A characteristic cultural landscape of the global society and of the information of the present times is being configured. It is no longer about knowing what country or what civilization is behind the elements that make up that aesthetic and that landscape. While the weight of some Western institutions, elites and power groups is undeniable, in an increasingly international process, contemporary landscapes acquire a series of forms that, because they are recognized all over the world, do not identify exclusively with any. The new industrial and labor-areas of Latin America or the Asian continent, and to a lesser extent of Africa, have added many of its elements to this international industrial aesthetic. Contemporary landscapes are increasingly recognizable in the world because they do not represent only one part of the planet, but represent an iconography and symbols that, although they were mostly born in the West, their model of democracy and industrial production, throughout the years they have been reinterpreted, modified, and nuanced, creating a mythology and an increasingly global and representative art of humanity.

Much remains to be done because, like any sociocultural builder, this aesthetic mythology of the global present camouflages relations of power, propaganda, and domination where the West and the new international institutions strive to make prevail in the global showcase that is globalization their own interests. Nothing new in the history of humanity. Therefore, we call the importance of disciplines such as Anthropology or Archeology, necessary not only to identify these relationships in the present, which socio-economic scenarios and power processes are camouflaged behind an aesthetic and a landscape that is perceived as contemporary and linked globally. The archaeological look must help to dissect the strata, relationships and elements of which that reality is composed, our reality, establish their genesis sequences and how they have arrived at the present. Archeology has to excavate and prospect the current reality as a tool to understand ourselves better and to help the formation of a world and a more conscious, civic and democratic society.

\section{References}

1. González Vergara Ó (2017) Historiographical Implications of the Introduction of Archaeology in Contemporary Societies' Studies, In: Fragio, A and Ros Velasco J Contemporary Approaches in Philosophical and Humanistic Thought, Aracne Editrice, Rome, Italy, pp. 131-156.

\section{Your next submission with Juniper Publishers will reach you the below assets}

- Quality Editorial service

- Swift Peer Review

- Reprints availability

- E-prints Service

- Manuscript Podcast for convenient understanding

- Global attainment for your research

- Manuscript accessibility in different formats

( Pdf, E-pub, Full Text, Audio)

- Unceasing customer service

Track the below URL for one-step submission https://juniperpublishers.com/online-submission.php 